\title{
Front Matter: Volume 9010
}

, "Front Matter: Volume 9010," Proc. SPIE 9010, Next-Generation Optical Networks for Data Centers and Short-Reach Links, 901001 (14 March 2014); doi: $10.1117 / 12.2063592$

SPIE. Event: SPIE OPTO, 2014, San Francisco, California, United States 


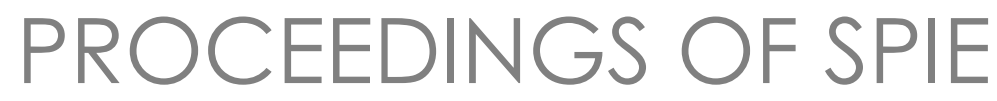

\title{
Next-Generation Optical Networks for Data Centers and Short-Reach Links
}

\author{
Atul K. Srivastava \\ Editor
}

4-5 February 2014

San Francisco, California, United States

Sponsored and Published by

SPIE 
The papers included in this volume were part of the technical conference cited on the cover and title page. Papers were selected and subject to review by the editors and conference program committee. Some conference presentations may not be available for publication. The papers published in these proceedings reflect the work and thoughts of the authors and are published herein as submitted. The publisher is not responsible for the validity of the information or for any outcomes resulting from reliance thereon.

Please use the following format to cite material from this book:

Author(s), "Title of Paper," in Next-Generation Optical Networks for Data Centers and Short-Reach Links, edited by Atul K. Srivastava, Proceedings of SPIE Vol. 9010 (SPIE, Bellingham, WA, 2014) Article CID Number.

ISSN: 0277-786X

ISBN: 9780819499233

Published by

SPIE

P.O. Box 10, Bellingham, Washington 98227-0010 USA

Telephone +1 3606763290 (Pacific Time) · Fax +1 3606471445

SPIE.org

Copyright @ 2014, Society of Photo-Optical Instrumentation Engineers.

Copying of material in this book for internal or personal use, or for the internal or personal use of specific clients, beyond the fair use provisions granted by the U.S. Copyright Law is authorized by SPIE subject to payment of copying fees. The Transactional Reporting Service base fee for this volume is $\$ 18.00$ per article (or portion thereof), which should be paid directly to the Copyright Clearance Center (CCC), 222 Rosewood Drive, Danvers, MA 01923. Payment may also be made electronically through CCC Online at copyright.com. Other copying for republication, resale, advertising or promotion, or any form of systematic or multiple reproduction of any material in this book is prohibited except with permission in writing from the publisher. The CCC fee code is 0277-786X/14/\$18.00.

Printed in the United States of America.

Publication of record for individual papers is online in the SPIE Digital Library.

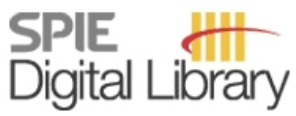

SPIEDigitallibrary.org

Paper Numbering: Proceedings of SPIE follow an e-First publication model, with papers published first online and then in print and on CD-ROM. Papers are published as they are submitted and meet publication criteria. A unique, consistent, permanent citation identifier (CID) number is assigned to each article at the time of the first publication. Utilization of CIDs allows articles to be fully citable as soon as they are published online, and connects the same identifier to all online, print, and electronic versions of the publication. SPIE uses a six-digit CID article numbering system in which:

- The first four digits correspond to the SPIE volume number.

- The last two digits indicate publication order within the volume using a Base 36 numbering

system employing both numerals and letters. These two-number sets start with 00, 01, 02, 03, 04, $05,06,07,08,09,0 A, 0 B \ldots$. 0Z, followed by 10-1Z, 20-2Z, etc.

The CID Number appears on each page of the manuscript. The complete citation is used on the first page, and an abbreviated version on subsequent pages. Numbers in the index correspond to the last two digits of the six-digit CID Number. 


\section{Contents}

vii Conference Committee

SESSION 1 OPTICAL COMMUNICATION PLENARY SESSION: JOINT SESSION WITH CONFERENCES 9007 AND 9008

901003 Data center networks and network architecture (Invited Paper) [9010-2]

H. Esaki, The Univ. of Tokyo (Japan)

SESSION 2 TOWARD 100G/400G FLEXIBLE SYSTEMS FOR ADVANCED ACCESS AND DATA CENTER NETWORKS: JOINT SESSION WITH CONFERENCES 9007, 9008, AND 9009

901004 A global standardization trend for high-speed client and line side transceivers (Invited Paper) [9010-3]

H. Isono, Fujitsu Optical Components Ltd. (Japan)

SESSION 3 NEXT-GENERATION INTEGRATED PHOTONICS DEVICES: JOINT SESSION WITH CONFERENCES 9007, 9008, AND 9009

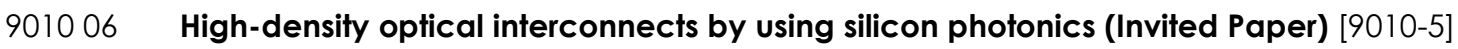
Y. Urino, T. Usuki, J. Fujikata, M. Ishizaka, K. Yamada, Institute for Photonics-Electronics Convergence System Technology (Japan) and Photonics Electronics Technology Research Association (Japan); T. Horikawa, Institute for Photonics-Electronics Convergence System Technology (Japan) and National Institute of Advanced Industrial Science and Technology (Japan); T. Nakamura, Institute for Photonics-Electronics Convergence System Technology (Japan) and Photonics Electronics Technology Research Association (Japan); Y. Arakawa, Institute for Photonics-Electronics Convergence System Technology (Japan) and The Univ. of Tokyo (Japan)

\section{SESSION 4 SHORT-REACH AND DATA CENTER NETWORKS}

901007 High-speed low-power short-reach optical interconnects for high-performance computing and servers (Invited Paper) [9010-6]

D. M. Kuchta, IBM Thomas J. Watson Research Ctr. (United States)

901008 Burst switching without guard interval in all-optical software-define star intra-data center network [9010-7]

P. N. Ji, T. Wang, NEC Labs. America, Inc. (United States) 
901009 Combined CATV and very-high-speed data transmission over a 1550-nm wavelength indoor optical wireless link [9010-9]

M. I. S. Chowdhury, M. Kavehrad, W. Zhang, P. Deng, The Pennsylvania State Univ. (United States)

SESSION 5 OPTICAL INTERCONNECTS AND DEVICES FOR SHORT-REACH NETWORKS: JOINT SESSION WITH CONFERENCE 9008

9010 OC A 25-Gb/s 100-m multi-mode fiber optical link based on $1.3 \mu \mathrm{m}$ lens-integrated surfaceemitting laser and CMOS receiver (Invited Paper) [9010-12]

T. Takemoto, H. Yamashita, Y. Matsuoka, K. Adachi, Y. Lee, Hitachi, Ltd. (Japan)

9010 OD The first Brazilian integrated 100G DPQPSK transmitter on a $4 \times 3 \mathrm{~mm}$ silicon photonic chip (Invited Paper) [9010-13]

J. C. R. F. de Oliveira, A. P. Freitas, F. G. Peternella, L. Matiolli, V. Corso, F. Borin,

B. C. Kyotoku, N. Guerreiro-Gonzalez, CPqD Foundation (Brazil)

SESSION 6 ADVANCED COMPONENTS FOR SHORT-HAUL SYSTEMS: JOINT SESSION WITH CONFERENCE 9008

9010 OF Silicon photonic Bragg-grating couplers for optical communications (Invited Paper) [9010-15]

W. Shi, Univ. Laval (Canada); V. Veerasubramanian, D. V. Plant, McGill Univ. (Canada);

N. A. F. Jaeger, L. Chrostowski, The Univ. of British Columbia (Canada)

9010 OG Monolithic silicon waveguides in bulk silicon wafers (Invited Paper) [9010-16] C.-M. Chang, Bell Labs., Alcatel-Lucent (United States); O. Solgaard, Stanford Univ. (United States)

$9010 \mathrm{OH} \quad$ Monolithically integrated Ge CMOS laser (Invited Paper) [9010-17]

R. Camacho-Aguilera, Massachusetts Institute of Technology (United States)

SESSION 7 PHOTONIC SWITCHING, ROUTING, AND WDM DEVICES: JOINT SESSION WITH CONFERENCE 9008

9010 ol Germanium light-emitting diodes on silicon for very-short-reach interconnect (Invited Paper) [9010-18]

M. Sagawa, K. Oda, K. Tani, Y. Suwa, J. Kasai, T. Okumura, S. Saito, T. Ido, Photonics Electronics Technology Research Association (Japan), Institute for Photonics-Electronics Convergence System Technology (Japan), and Hitachi, Ltd. (Japan)

9010 0J Advances in silicon photonics WDM devices (Invited Paper) [9010-19] P. P. Absil, P. De Heyn, IMEC (Belgium); P. Dumon, D. Van Thourhout, IMEC (Belgium) and Univ. Gent (Belgium); P. Verheyen, S. Selvaraja, G. Lepage, M. Pantouvaki, M. Rakowski, J. Van Campenhout, IMEC (Belgium) 
POSTER SESSION

9010 OK Optimization of spectral band utilization in gridless WDM optical network [9010-8]

I. B. Martins, Lab. Traitement et Communication de I'Information, CNRS, Télécom ParisTech (France); I. Aldaya, Tecnológico de Monterrey (Mexico); G. Perez-Sanchez, Ctr. de Investigación e Innovación Tecnológica, Instituto Politécnico Nacional (Mexico); P. Gallion, Lab. Traitement et Communication de I'Information, CNRS, Télécom ParisTech (France)

Author Index 
Proc. of SPIE Vol. $9010901001-6$

Downloaded From: https://www.spiedigitallibrary.org/conference-proceedings-of-spie on 26 Apr 2023 Terms of Use: https://www.spiedigitallibrary.org/terms-of-use 


\section{Conference Committee}

Symposium Chairs

David L. Andrews, University of East Anglia Norwich (United Kingdom)

Alexei L. Glebov, OptiGrate Corporation (United States)

Symposium Co-chairs

Jean Emmanuel Broquin, IMEP-LAHC (France)

Shibin Jiang, AdValue Photonics, Inc. (United States)

Program Track Chair

Benjamin B. Dingel, Nasfine Photonics, Inc. (United States)

Conference Chair

Atul K. Srivastava, NEL America, Inc. (United States)

Conference Program Committee

Philippe Absil, IMEC (Belgium)

Júlio César R. F. de Oliveira, Fundacao CpqD (Brazil)

Mitchell H. Fields, Avago Technologies (United States)

Hideki Isono, Fujitsu Optical Components, Ltd. (Japan)

Takashi Saida, NTT Photonics Laboratories (Japan)

Ivan Shubin, Oracle (United States)

Takashi Takemoto, Hitachi, Ltd. (Japan)

Session Chairs

1 Optical Communications Plenary Session: Joint Session with Conferences 9007 and 9008

Benjamin B. Dingel, Nasfine Photonics, Inc. (United States)

Atul K. Srivastava, NEL America, Inc. (United States)

2 Toward 100G/400G Flexible Systems for Advanced Access and Data Center Networks: Joint Session with Conferences 9007, 9008, and 9009

Werner Weiershausen, Deutsche Telekom AG (Germany)

Xiang Zhou, AT\&T Laboratories Research (United States) 
3 Next-Generation Integrated Photonics Devices: Joint Session with Conferences 9007, 9008, and 9009

Atul K. Srivastava, NEL America, Inc. (United States)

Benjamin B. Dingel, Nasfine Photonics, Inc. (United States)

4 Short-Reach and Datacenter Networks

Takashi Takemoto, Hitachi, Ltd. (Japan)

Philippe Absil, IMEC (Belgium)

5 Optical Interconnects and Devices for Short-Reach Networks: Joint Session with Conference 9008

Hideki Isono, Fujitsu Ltd. (Japan)

Ivan Shubin, Oracle (United States)

6 Advanced Components for Short-Haul Systems: Joint Session with Conference 9008

Krishna Swaminathan, Intel Corporation (United States)

Achyut K. Dutta, Banpil Photonics, Inc. (United States)

7 Photonic Switching, Routing, and WDM Devices: Joint Session with Conference 9008

Kiyo Ishii, National Institute of Advanced Industrial Science and Technology (Japan)

Idelfonso Tafur Monroy, DTU Fotonik (Denmark) 